\title{
Kompetensi Manajerial Kepala Sekolah dalam Meningkatkan Kinerja Guru Sekolah Dasar
}

\author{
Rahman Tanjung', Hanafiah², Opan Arifudin ${ }^{3}$, Dedi Mulyadi ${ }^{4}$ \\ ${ }^{1}$ Widyaiswara BKPSDM Kabupaten Karawang \\ 2,3 Universitas Islam Nusantara Bandung \\ ${ }^{4}$ SMA Negeri 25 Garut \\ E-mail: rahmantanjung1981@gmail.com
}

\begin{abstract}
Article Info
Article History

Received: 2021-07-12

Revised: 2021-08-15

Published: 2021-08-26

Keywords:

Managerial;

Principal;

Teacher.

Abstract

The purpose of this study was to determine the planning, implementation, evaluation and solutions in improving the performance of elementary school teachers. This study uses a qualitative approach. The collection of data obtained from various sources, backgrounds, and various ways in this research is through library research. The results of this study indicate that the principal's competence in improving the performance of elementary school teachers, namely in planning the principal to make the school's annual work plan (RKTS) which involves 8 educational standards, provides SKP criteria (employee performance targets) at the beginning of the year as a guide for teacher assessment by principals and DP3 concerning teacher behavior assessment, in practice holding and involving teachers in scientific forums such as education and training (upgrading/inservice training, workshops, and seminars) In the evaluation, the Principal supervises the education of teachers (class visit techniques, private talks, and group discussions), as well as the efforts made by the Principal as a manager in improving performance is to build good communication with all teachers in building a positive work culture productive.
\end{abstract}

\begin{tabular}{l}
\hline Artikel Info \\
\hline Sejarah Artikel \\
Diterima: 2021-07-12 \\
Direvisi: 2021-08-15 \\
Dipublikasi: 2021-08-26
\end{tabular}

Kata kunci:

Manajerial;

Kepala Sekolah; Guru.

\begin{abstract}
Abstrak
Tujuan penelitian ini adalah untuk mengetahui perencanaan, pelaksanaan, evaluasi dan solusi dalam meningkatkan kinerja guru Sekolah dasar. Penelitian ini menggunakan pendekatan kualitatif. Pengumpulan data yang diperoleh dari berbagai sumber, latar, dan beragam cara pada penelitian ini adalah melalui studi kepustakaan. Hasil penelitian ini menunjukkan bahwa kompetensi Kepala Sekolah dalam meningkatkan kinerja guru Sekolah dasar, yaitu dalam perencanaan Kepala sekolah membuat rencana kerja tahunan sekolah (RKTS) yang menyangkut 8 standar pendidikan, memberikan kriteria SKP (sasaran kinerja pegawai) pada awal tahun sebagai pedoman penilaian guru oleh kepala sekolah dan DP3 yang menyangkut penilaian perilaku guru, dalam pelaksanaannya mengadakan dan mengikutsertakan guru dalam forum ilmiah seperti pendidikan dan pelatihan (upgrading/inservice training, workshop, dan seminar), dalam evaluasi Kepala Sekolah melakukan supervisi pendidikan terhadap para guru (teknik kunjungan kelas, pembicaraan pribadi, dan diskusi kelompok), serta upaya yang dilakukan Kepala Sekolah sebagai manajer dalam meningkatkan kinerja adalah membangun komunikasi yang baik dengan semua guru dalam membangun budaya kerja yang produktif.
\end{abstract}

\section{PENDAHULUAN}

Pendidikan pada era revolusi industri seperti saat ini memiliki peranan penting dalam mengembangkan sumber daya manusia, Keberadaan sumber daya Manusia (SDM) yang berkualitas dan mampu bersaing dalam berbagai aspek kehidupan dan sangat menentukan keberhasilan tujuan nasional dan kemajuan Negara Indonesia, ketersediaan sumber daya manusia (SDM) yang berkualitas dalam dunia pendidikan dapat membantu mewujudkan prestasi belajar siswa dan meningkatkan mutu pendidikan. Menurut (Irwansyah, 2021) bahwa banyak aspek yang dapat menentukan mutu sekolah diantaranya adalah fasilitas yang dimiliki sekolah, sumber dana, sumber daya manusia, dukungan orang tua/masyarakat, faktor input siswa, dan manajemen sekolah, dalam penyelenggaraan pendidikan di Sekolah, menurut (Arifudin, 2021) bahwa Iklim yang kondusif dilingkungan sekolah dapat dipengaruhi dan ditentukan oleh beberapa hal diantaranya adalah peranan kepala sekolah. Ada hubungan yang tak dapat dipisahkan antara kemampuan 
manajerial kepala sekolah, kinerja guru dan mutu pendidikan. Kemampuan manajerial kepala sekolah akan sangat mempengaruhi kinerja guru dan kinerja guru itu sendiri akan mempengaruhi prestasi siswa.

Menurut Wahjosumidja dalam (Tanjung, 2020) mendefinisikan Kepala Sekolah adalah seorang tenaga fungsional guru yang diberi tugas untuk memimpin suatu sekolah, yang diselenggrakan proses belajar mengajar, atau interaksi antara guru dan siswa, dalam pelaksanaan pembelajaran, kepala sekolah mempunyai tanggung jawab yang sangat besar dalam upaya meningkatkan mutu sekolah, Kepala sekolah dituntut mampu melakukan pengelolaan terhadap seluruh sumber daya yang ada untuk menciptakan proses pembelajaran berlangsung secara efektif dan efisien. Adapun pengertian Kepala Sekolah sesuai dengan Peraturan Menteri Pendidikan Nasional Nomor 28 Tahun 2010 tentang Penugasan Guru sebagai Kepala Sekolah/Madrasah, Pasal 1 ayat 1 yaitu : Kepala Sekolah/Madrasah adalah guru yang diberi tugas tambahan untuk memimpin taman kanakkanak/raudhotul athfal (TK/RA), taman kanakkanak luar biasa (TKLB), sekolah/madrasah ibtidaiyah (SD/MI), sekolah dasar luar biasa (SDLB), sekolah menengah pertama/madrasah tsanawiyah (SMP/MTs), sekolah menengah pertama luar biasa (SMPLB), sekolah menengah atas/madrasah Aliyah (SMA/MA), sekolah menengah kejuruan/madrasah aliyah kejuruan (SMK/MAK), sekolah menengah atas luar biasa (SMALB) yang bukan sekolah bertaraf internasioanal (SBI) atau yang tidak dikembangkan menjadi sekolah bertaraf internasional (SBI).

Eksistensi kepala sekolah yang efektif merupakan faktor yang sangat penting karena meskipun sekolah memiliki sarana dan prasarana pendidikan yang memadai, dana yang cukup dan potensi sumber daya manusia yang standar, semuanya akan sia-sia bilamana kepala sekolah tidak mampu mengelola secara professional. Menurut (Juhji, 2020) bahwa Kepala sekolah memiliki kedudukan yang sangat penting sehingga kepala sekolah dituntut untuk memiliki kemampuan dan kesiapan untuk mempengaruhi, mendorong, mengajak, menuntun, menggerakkan, mengarahkan dan selanjutnya berbuat sesuatu yang dapat membantu tercapainya suatu tujuan yang telah ditetapkan, Menurut Nur Aedi dalam (Nadeak, 2020) bahwa Kepala Sekolah sebagai manajer memiliki peran dalam menetukan proses pengelolaan manajemen sekolah. Berhasil atau tidaknya tujuan sekolah dapat dipengaruhi oleh kemampuan Kepala Sekolah dalam menjalankan fungsi-fungsi manajemen, yang terdiri dari perencanaan, pengorganisasian, pelaksanaan, dan pengawasan.

Sesuai dengan Keputusan Mendiknas tentang kompetensi manajerial, salah satunya bahwa Kepala Sekolah harus mampu melaksanakan manajerial sekolah, dan kinerjanya harus terlihat dalam melaksanakan bidang garapan manajerial tersebut. Stoner pun berpendapat dalam (Tanjung, 2020) menyatakan bahwa: Ada delapan macam fungsi manajer dalam suatu organisasi, yaitu Kepala Sekolah : bekerja dengan dan melalui orang lain, bertanggung jawab dan mempertanggungjawabkan, mampu mengahadapi berbagai kondisi yang terbatas, berpikir secara analistik dan konseptual, sebagai juru penengah, sebagai politisi, sebagai diplomat, dan berfungsi sebagai pengambil keputusan, Menurut (Arifudin, 2018) bahwa lembaga pendidikan merupakan organisasi yang harus dikelola dengan menggunakan pendekatan manajemen agar mampu mencapai tujuan dari organisasi. Kepala Sekolah sebagai pimpinan Sekolah memiliki fungsi sebagai manajer dalam mengelola Sekolah dan menyelenggarakan proses pendidikan. Dengan tugasnya sebagai seorang manajer Sekolah, kepala sekolah memiliki syarat-syarat yang dipenuhi pengangkatannya sebagai seorang kepala sekolah.

Kemampuan kepala sekolah sebagai seorang manajerial yang mengelola sekolah sebagai sebuah organisasi pendidikan berperan dalam pembuat perencanaan-perencanaan sebagai tujuan sekolah sebagai sebuah organisasi yang bertujuan untuk mencapai tujuan yang telah ditetapkan oleh semua warga Sekolah. Dalam hal pengembangan organisasi juga kepala sekolah menguasai teori dan seluruh kebijakan pendidikan nasional dalam mengembangkan organisasi Sekolah, prinsip efisiensi dan efektifitas pengembangann harus diutamakan. Berdasarkan hal ini menurut (Arifudin, 2021) bahwa Kepala Sekolah bertanggung jawab sebagai seorang manajer dalam mengelola Sekolah untuk mencapai tujuan Sekolah. Termasuk di dalamnya adalah mengelola sumber daya manusia (SDM) yaitu guru sebagai pelaksana pembelajaran yang memiliki peran dalam mencapai tujuan pendidikan dan Sekolah, selain kemampuan manajerial kepala sekolah, peran guru juga sangat mempengaruhi proses pembelajaran yang efektif yang dapat 
meningkatkan prestasi siswa. Oleh karena itu keberadaan guru yang memiliki kompetensi yang baik dalam lembaga pendidikan akan dapat meningkatkan prestasi belajar siswa dan dapat meningkatkan mutu pendidikan. Menurut (Mulyadi, 2021) bahwa guru menjadi salah satu faktor penentu keberhasilan setiap upaya pendidikan. Untuk itu setiap ada perubahan kurikulum dan peningkatan sumber daya manusia yang dihasilkan dari upaya pendidikan selalu bermuara pada faktor guru, tidak dapat dipungkiri bahwa banyak masyarakat beranggapan bahwa keberhasilan suatu pendidikan sangat ditentukan oleh mutu guru itu sendiri. Sementara diketahui bersama keberhasilan atau kegagalan pendidikan sebenarnya dipengaruhi oleh banyak faktor, salah satunya yaitu kinerja guru.

Berdasarkan keempat kompetensi manajerial kepala Sekolah tersebut, ditemukan beberapa permasalahan diantaranya adalah sebagai berikut:

a) Perencanaan menjadi salah satu keterampilan yang penting, mengingat perencanaan yang baik merupakan setengah dari kesuksesan suatu pekerjaan. Prinsip perencanaan yang baik, akan selalu mengacu pada: pertanyaan: "Apa yang dilakukan (what), siapa yang melakukan (who), kapan dilakukan (when). Di mana dilakukan (where), dan bagaimana sesuatu dilakukan (how)", Detail perencanaan inilah yang dapat menjadi kunci kesuksesan suatu pekerjaan. Permasalahan dalam bidang perencanaan yang dimiliki sekolah yang diteliti antara lain: 1) Kegiatan perencanaan yang dibuat oleh kepala sekolah setiap tahunnya sama dan perencanaan yang dibuat belum berdasarkan hasil analisa atau evaluasi kegiatan pada tahun-tahun sebelumnya. 2) Didalam membuat perencanaan sekolah, kepala sekolah tidak melaksanakan rapat terlebih dahulu dengan para PTK (pendidik dan tenaga kependidikan) sehingga perencanaan yang dibuat tidak sesuai dengan kebutuhan guru dan sekolah. 3) Perencanaan sekolah yang di buat hanya untuk memenuhi persyaratan administrasi.

b) Pengorganisasian dalam lingkungan Sekolah mempunyai sumber daya yang cukup besar mulai dari sumber daya manusia yang terdiri dari guru, karyawan, dan siswa, sumberdaya keuangan, hingga fisik mulai dari gedung serta sarana dan prasarana yang dimiliki. Masalah yang terjadi di sekolah antara lain: 1) Kepala Sekolah belum menyesuaikan kemampuan setiap guru dengan fungsi dan tanggung jawab yang diberikan. 2) Kepala sekolah belum bisa memanfaatkan seluruh sumber daya manusia secara optimal. Penggunaan sumber daya manusia tertumpu pada tenaga honorer. 3) Banyak guru yang sudah senior dan berusia lanjut yang mendekati masa pensiun sulit mengikuti perubahan sistem terkait dengan masalah administrasi dan proses pembelajaran yang mengalami perubahan dengan menggunakan media teknologi computer, adanya kesulitan mengatasi masalah sumber daya manusia (SDM) atau guru ini karena kepala sekolah segan untuk mengatur guru senior terkait tanggung jawabnya sebagai seorang guru dan membangun komunikasi lebih baik dengan guru sehingga berdampak kepada produktifitas guru-guru khususnya yang senior tidak optimal dalam berkontribusi pada penyelenggaraan pendidikan.

c) Kemampuan melaksanakan pekerjaan sesuai dengan perencanaan yang telah ditetapkan. Kepala sekolah membangun prosedur operasional lembaga pendidikan, memberi contoh bagaimana bekerja, membangun motivasi dan kerjasama, serta selalu melakukan koordinasi dengan berbagai elemen pendidikan. Permasalahan yang muncul pada bagian ini adalah perencanaan yang telah disusun dalam implementasinya tidak dilakukan secara sungguh-sungguh dan professional.

d) Tugas Kepala sekolah dalam melakukan tugastugas pengawasan dan pengendalian. Pengawasan (supervisi) ini meliputi supervisi manajemen dan juga supervisi dalam bidang pengajaran, supervisi manajemen artinya melakukan pengawasan dalam bidang pengembangan keterampilan dan kompetensi adminstrasi dan kelembagaan, sementara supervisi pengajaran adalah melakukan pengawasan dan kendali terhadap tugas-tugas serta kemampuan tenaga pendidik sebagai seorang guru, Kepala sekolah yang memiliki kompetensi dan keterampilan professional sebagai guru akan mampu memberikan supervisi yang baik kepada bawahannya. Permasalahan yang terjadi di Sekolah adalah kepala sekolah belum melaksanakan supervisi kepada bawahannya secara rutin, supervisi hanya dilakukan pada saat penilaian kinerja guru saja.

Fungsi kepala sekolah belum bisa dilaksanakan secara keseluruhan, hal ini dikarenakan tugas dan tanggung jawab kepala 
sekolah yang sangat banyak dan luas, kepala sekolah tidak hanya bertanggung jawab atas kelancaran jalannya sekolah secara teknis akademis saja, banyak masalah-masalah yang dihadapi oleh kepala sekolah yang dituntut segera dipecahkan dan dilaksanakan, seperti kekurangan ruang belajar, gedung sekolah yang sudah rusak, perlengkapan gedung yang sangat kurang dan tidak memenuhi syarat, tidak adanya alat-alat pelajaran, buku-buku pelajaran yang hampir setiap tahun berubah, media teknologi penunjang pembelajaran, cara penampungan murid baru yang setiap tahun bertambah, kekurangan tenaga guru dan kesulitan pengangkatannya.

Berdasarkan masalah-masalah ini perlu dilakukan penelitian lebih lanjut supaya dapat di temukan data yang valid dan sekaligus dapat ditentukan alternatif pemecahannya. Sehingga penulis mengangkat judul "Kompetensi Manajerial Kepala Sekolah Dalam Meningkatkan Kinerja Guru Sekolah Dasar".

\section{METODE PENELITIAN}

Penelitian kompetensi manajerial kepala sekolah dalam meningkatkan kinerja guru Sekolah dasar menggunakan pendekatan kualitatif, Menurut Sugiyono dalam (Nasser, 2021) bahwa metode penelitian kualitatif adalah metode penelitian yang digunakan untuk meneliti pada kondisi obyek yang alamiah dimana peneliti adalah sebagai instrumen kunci, dalam penelitian kualitatif memiliki karakteristik analisis tekstual atau dalam pandangan Creswell sebagaimana dikutip (Tanjung, 2019) bahwa penelitian kualitatif merupakan penelitian interpretatif, yang di dalamnya peneliti terlibat dalam pengalaman yang berkelanjutan dan terus menerus dengan para partisipan, adapun metode dalam penelitian ini adalah deskriptif analisis, dalam hal pengumpulan data yang diperoleh dari berbagai sumber, latar, dan beragam cara pada penelitian ini adalah melalui studi kepustakaan, studi kepustakaan merupakan langkah awal dalam metode pengumpulan data. Studi pustaka merupakan metode pengumpulan data yang diarahkan kepada pencarian data dan informasi melalui dokumen-dokumen, baik dokumen tertulis, foto-foto, gambar, maupun dokumen elektronik yang dapat mendukung dalam proses penulisan, menurut Sugiyono sebagaimana dikutip (Juhadi, 2020) dokumen merupakan catatan peristiwa yang sudah berlalu, dokumen bisa berbentuk gambar tulisan, gambar, atau karya-karya monumental dari seseorang, hal itu, sejalan dengan pendapat Creswell dalam (Rusmana, 2020) bahwa dokumen-dokumen kualitatif (qualitatif document) bisa berupa dokumen publik (misalnya koran, makalah, laporan kantor) ataupun dokumen privat (mislanya buku harian, diari, surat, e-mail).

\section{HASIL DAN PEMBAHASAN}

Berdasarkan hasil penelitian bahwa kompetensi manajerial kepala sekolah dalam meningkatkan kinerja guru sekolah dasar dilakukan dengan tahapan perencanaan, pelaksanaan, evaluasi dan solusi dalam meningkatkan kinerja guru Sekolah dasar.

a) Perencanaan Kompetensi Manajerial Kepala Sekolah Dalam Meningkatkan Kinerja Guru Sekolah Dasar

Kompetensi Kepala Sekolah sebagai seorang manajer dalam upaya meningkatkan kinerja guru merupakan dasar acuan dalam melaksanakan keseluruhan rangkaian kegiatan, perencanaan dilakukan dalam rangka meningkatkan kinerja guru di Sekolah Dasar, adapun rencana Kepala Sekolah sebagai seorang manajer dalam upaya meningkatkan kinerja guru dilakukan berdasarkan pada visi misi Sekolah sebagai analisis kebutuhan, proses rekrutmen guru baru sesuai dengan kebutuhan kompetensi bukan berdasar kepada titipan atau kekeluargaan, membuat rencana kerja tahunan sekolah (RKTS) yang menyangkut 8 standar pendidikan, memberikan kriteria SKP (sasaran kinerja pegawai) pada awal tahun sebagai pedoman penilaian guru oleh kepala sekolah dan DP3 yang menyangkut penilaian perilaku guru, serta Kepala sekolah membuat rencana supervisi, rencana pemeriksaan administrasi dan membuat jadwal guru untuk mengikut sertakan guru dalam bintek, seminar, KKG maupun memberikan izin melanjutkan pendidikan atau melinearkan bagi guru yang belum linear.

b) Pelaksanaan Kompetensi Manajerial Kepala Sekolah Dalam Meningkatkan Kinerja Guru Sekolah Dasar

Dalam meningkatkan kinerja guru Kepala Sekolah sebagai seorang manajer, pelaksanaan (actuating) merupakan suatu tahapan yang sangat penting sebagai tindak lanjut dari perencanaan yang telah dibuat Sekolah Dasar dalam upaya meningkatkan kinerja guru. Kepala Sekolah sebagai manajer 
dalam peningkatan kinerja guru telah melaksanakan berbagai kagiatn untuk mendorong peningkatan kinerja guru dengan mengikutsertakan guru dalam forum ilmiah seperti pendidikan dan pelatihan (upgrading/ inservice training, workshop, dan seminar), penyediaan fasilitas penunjang guru dalam proses pembelajaran, mengikutser-takan guru dalam program sertifikasi guru, serta memberikan kesempatan melanjutkan pendidikan formal pada guru.

c) Evaluasi Kompetensi Manajerial Kepala Sekolah Dalam Meningkatkan Kinerja Guru Sekolah Dasar

Evaluasi dari Kepala Sekolah sebagai seorang manajer dalam upaya meningkatkan kinerja guru bertujuan untuk mengetahui tingkat keterlaksanaan kegiatan dan ketercapaian tujuan yang telah ditetapkan di Sekolah Dasar, pelaksanan evaluasi dari Kepala Sekolah sebagai seorang manajer dalam upaya meningkatkan kinerja guru dilakukan saat proses pembelajaran berlangsung maupun selesainya tahun ajaran pendidikan dalam rangka melihat ketercapaian program, Sasaran maupun aspek yang dievaluasi adalah kehadiran guru (presensi), kinerja guru, prestasi dan perkembangan siswa, catatan kelas dalam hal ini adalah hasil tes siswa, silabus dan RPP guru, media dan metode yang digunakan guru, serta apabila terdapat guru yang memiliki kendala secara pribadi kepala sekolah membicarakan secara pribadi masalah apa yang sedang dihadapi guru tersebut, kemudian dicarikan solusinya.

d) Solusi Kompetensi Manajerial Kepala Sekolah Dalam Meningkatkan Kinerja Guru Sekolah Dasar

Upaya yang dilakukan dalam peran manajerial Kepala Sekolah menghadapi faktor penghambat yang terjadi dalam meningkatkan kinerja guru adalah Memaksimalkan ketersediaan sarana prasarana sekolah yang ada dan mengajak guru untuk berusaha kreatif dalam penyedian media belajar dalam mendukung meningkatkan kinerja guru dalam proses pemebelajaran, berkaitan dengan program sertifikasi guru, Kepala Sekolah memberikan solusi terkait ada beberapa guru mata pelajaran yang kekurangan jam mengajar mencarikan lembaga pendidikan yang aksesnya tidak jauh dari Sekolahnya, bekerja sama dengan pihak swasta untuk mengatasi kurangnya alokasi dana dalam menunjang perbaikan kinerja guru dengan berbagai kegiatan, serta membangun komunikasi yang baik dengan komite sekolah dalam upaya meningkatkan partisipasi masyarakat dalam mendukung penyelenggaraan pendidikan.

\section{KESIMPULAN DAN SARAN \\ A. SIMPULAN}

Kompetensi manajerial kepala sekolah di Sekolah Dasar dalam meningkatkan kinerja guru telah menyelenggarakan sesuai dengan tahapan-tahapan manajemen dengan baik. Fungsi manajerial Kepala Sekolah sebagai salah satu upaya dalam meningkatkan kinerja guru, penyelenggaraan fungsi manajerial Kepala Sekolah dengan pendekatan manajemen pendidikan yang dilakukan oleh Kepala Sekolah sudah menjalankan tahapantahapan dari manajemen yang meliputi perencanaan, pelaksanaan, dan evaluasi namun secara fungsi manajemen belum dioptimalkan, dalam menjalankan pendekatan manajemen pendidikan pada proses fungsi manajerial Kepala Sekolah tersebut, Kepala Sekolah sebagai manajer sudah menjalankan setiap tahapan manajemen pada penyelenggaraan pendidikan dalam rangka meningkatkan kinerja guru.

\section{B. SARAN}

Adapun saran yang dapat disampaikan berdasarkan pada hasil penelitian ini, yaitu sebagai berikut :

a) Bagi Kepala Sekolah harus mampu mengelola lembaga pendidikan sesuai dengan manajemen yang baik dan mampu mendorong fungsi dari guru sebagai pelaksanaan proses pendidikan untuk memaksimalkan kinerjanya dengan berbagai kegiatan yang ditetapkan pemerintah dalam menunjang profesinya, memfasilitasi sarana prasarana yang dibutuhkan oleh guru dalam pembelajaran agar sesuai dengan tujuan yang ditetapkan dan memaksimalkan fungsi guru dalam proses pembelajaran, mampu berkomunikasi dengan komite sekolah atau pihak lainnya untuk mendukung penyelenggaraan proses pendidikan terutama terkait dengan peningkatan kompetensi dan kinerja guru, serta mampu mengelola dan mengawasi penyelen-ggaraan peningkatan kinerja guru dengan membuat 
perencanaan, pelaksanaan, dan evaluasi yang jelas dan terukur sebagai upaya untuk meningkatkan kinerja guru.

b) Bagi Guru, hendaknya harus memiliki motivasi yang kuat terkait dengan perkembangan teknologi sebagai media bantu proses pendidikan sehingga mampu mengoperasikan teknologi yang perlu digunakan dalam penyelenggaraan proses pembelajaran.

\section{DAFTAR RUJUKAN}

Arifudin, O. (2021). Manajemen Strategik Teori Dan Implementasi. Banyumas : Pena Persada.

Arifudin, 0. (2021). Konsep Dasar Pendidikan Anak Usia Dini. Bandung: Widina Bhakti Persada Bandung.

Arifudin, O. (2018). Pengaruh Pelatihan Dan Motivasi Terhadap Produktivitas Kerja Tenaga Kependidikan STIT Rakeyan Santang Karawang. MEA (Manajemen, Ekonomi, \& Akuntansi), 2(3), 209-218.

Irwansyah, R. (2021). Perkembangan Peserta Didik. Bandung : Widina Bhakti Persada.

Juhadi. (2020). Pengaruh Sistem Pengendalian Internal Dan Audit Internal Terhadap Pelaksanaan Good Corporate Governance. Jemasi: Jurnal Ekonomi Manajemen Dan Akuntansi, 16(2), 17-32.

Juhji. (2020). Manajemen Humas Sekolah.
Bandung: Widina Bhakti Persada.

Mulyadi, D. (2021). Implementasi Kurikulum 2013 (Revisi) Di Sekolah Menegah Atas Pada Mata Pelajaran Peminatan. Jurnal Pendidikan Glasser, 5(1), 7-22.

Nasser, A. A. (2021). Sistem Penerimaan Siswa Baru Berbasis Web Dalam Meningkatkan Mutu Siswa Di Era Pandemi. Biormatika: Jurnal Ilmiah Fakultas Keguruan Dan Ilmu Pendidikan, 7(1), 100-109.

Rusmana, F. D. (2020). Pengaruh Gaya Kepemimpinan Transformasional Dan Transaksional Dengan Kinerja Karyawan BRI Syariah Subang. Jurnal Makro Manajemen, 5(2), 157-163.

Tanjung, R. (2020). Kepemimpinan \& Prilaku Organisasi Konsep Dan Perkembangan. Bandung: Widina Bhakti Persada.

Tanjung, R. (2020). Pengaruh Penilaian Diri Dan Efikasi Diri Terhadap Kepuasan Kerja Serta Implikasinya Terhadap Kinerja Guru. Jurnal Ilmiah MEA (Manajemen, Ekonomi, Dan Akuntansi), 4(1), 380-391.

Tanjung, R. (2019). Manajemen Pelayanan Prima Dalam Meningkatkan Kepuasan Mahasiswa Terhadap Layanan Pembelajaran (Studi Kasus di STIT Rakeyan Santang Karawang). MEA (Manajemen, Ekonomi, \& Akuntansi), 3(1), 234-242. 